\section{Enkel bok om biokjemi for de som ønsker det enkelt}

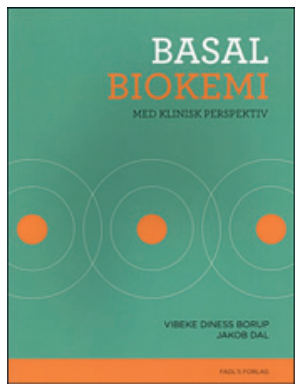

Vibeke Diness Borup, Jacob Dal Basal biokemi med klinisk perspektiv 249 s, tab, ill. København: FADL's Forlag, 2012. Pris DKK 350 ISBN 978-87-7749-651-6

Denne boken presenteres som en basisbok hvor forfatterne systematisk gjennomgår den biokjemiske bakgrunnen for kroppens funksjoner, med et visst innslag av kliniske sammenhenger og problemstillinger. Boken er inndelt i 15 kapitler og har et stikkordregister som står i forhold til innholdet. Teksten er lettlest, til tross for at den er på dansk, ikke minst når man har lært seg at brint er hydrogen og ilt er oksygen.

Forfatterne begynner med en enkel og nyttig innføring i kjemiske prinsipper. Deretter kommer de klassiske kapitlene som man finner i enhver lærebok i biokjemi, hvor man beskriver hver enkelt av de store molekylgruppene proteiner, karbohydrater og lipider og emneområder som membranstruktur, enzymer, væske- og elektrolyttbalanse, DNA og gener. I tillegg er det to kapitler hvor forfatterne strukturert beskriver ulike metabolske prosesser. Ganske ulikt andre lærebøker i biokjemi er det inkludert egne kapitler om tarmfunksjon og fordøyelse, lever, vitaminer og hemostase. I hvert kapittel har forfatterne inkludert egne rammer for fordypning og rammer hvor de beskriver sammenhengen mellom biokjemi/patobiokjemi og ulike kliniske tilstander. Stort sett gir disse rammene gode og illustrerende eksempler på aktuelle kliniske tilstander, men ikke allitid. Eksempel på det siste er de fem rammene for Klinikk i kapitlet om karbohydrater - Hyperglycemi og diabetes mellitus, Hypoglycemi, Galaktosemi, Fruktosuri og fruktoseintoleranse og Glycering av proteiner ved diabetes mellitus. De to første har helt klart sin plass i denne sammenhengen, mens de to neste beskriver svært sjeldne tilstander som virker malplassert $i$ en såpass lite omfattende lærebok. Likeledes er det i samme kapittel to rammer for fordypning, en for Glykemisk indeks og en for Fibre i kosten. I et område av biokjemien som er preget av kompliserte metabolske prosesser, burde det være enkelt å finne mer relevante områder for fordypning. Et annet eksempel på at forfatterne er selektive i hva de presenterer, er at det $\mathrm{i}$ kapitlet om vitaminer er en relativt omfattende omtale av omsetningen av folsyre og vitamin B12 (dog uten biokjemiske detaljer), og beskrivelsen av megaloblastær anemi og diagnostikk av denne er som i en bok i medisinsk biokjemi. Derimot er jernmangel, den hyppigste formen for anemi, ikke nevnt i noen sammenhenger.

Ifølge forordet er målgruppen hovedsakelig sykepleiestudenter. Hvis denne boken brukes som pensumbok, vil det også være behov for en mer omfattende oppslagsbok. Forfatterne nevner også at medisinstudenter med fordel kan benytte boken. Det er ikke åpenbart at denne boken kan erstatte den litteraturen medisinstudenter bruker i dag.

Dette er boken for dem som ikke har lært biokjemi tidligere, og som ønsker en kort innføring om de store linjene uten kompliserende detaljer. Dette er også boken for dem som en gang for lenge siden har lært biokjemi som fag, og som ønsker en enkel oppfriskning av gamle kunnskaper.

\section{Kort om væske- og elektrolyttbehandling}

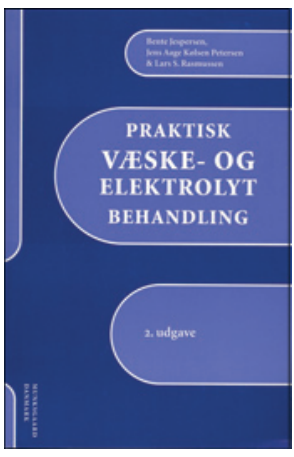

Bente Jespersen, Jens Aage Kølsen Praktisk væske og elektrolytbehandling

2. utg., 96 s, tab, ill. København: Munksgaard

Danmark, 2011. Pris DKK 148

ISBN 978-87-628-0998-7

Dette er en kortfattet introduksjon til et viktig klinisk tema: væskeog elektrolyttbehandling. Boken, eller heftet, med sine 94 sider skulle være overkommelig for de fleste i løpet av noen få timer. Innholdet er organisert i 22 korte kapitler fra en generell omtale av væskebalanse og de viktigste elektrolyttene (natrium, kalium, kalsium og magnesium) til en rekke kliniske tilstander hvor væskeeller elektrolyttforstyrrelser forekommer ofte, for eksempel ved nyresvikt, diabetes og gastrointestinale tap.

Boken er på dansk, velskrevet og lettlest. Stort sett er stoffet behandlet tilfredsstillende, med den plassen som er til rådighet. Mest er kanskje å utsette på det forfatterne ikke har tatt med.

Omtalen av syre-base-forstyrrelser er ikke behandlet i dybden. Kun et kort kapittel på knappe fire sider er viet slike problemer, og boken kan selvsagt ikke anbefales hvis det er dette leseren leter etter. Egentlig er dette litt synd, da syre-base-forstyrrelser og væske- eller elektrolyttforstyrrelser ofte må forstås i en sammenheng, og ikke hver for seg.

Et annet forhold som bør bemerkes, er fravær av omtale av fosfatforstyrrelser. Både magnesium og kalsium er tilgodesett med egne kapitler, mens fosfat ikke er nevnt i det hele tatt, heller ikke i stikkordregisteret. Hypofosfatemi er viktig å kjenne til og er ikke uvanlig, for eksempel innen intensivmedisin som ved underernæring (reernæringssyndrom). Man ser ofte hyperfosfatemi ved akutt nyresvikt. Likedan kunne godt sepsis vært behandlet i et eget kapittel. Som årsak til sjokk dominerer sepsis fullstendig på sykehus og er langt hyppigere enn mange av de andre kliniske problemstillinger som forfatterne behandler. Det er å håpe at begge disse forholdene er rettet opp ved neste (tredje) utgave.

Jeg kan anbefale boken for alle som ønsker en rask og oppdatert gjennomgang av væske- og elektrolyttbehandling. Den er imidlertid ikke tilstrekkelig verken som grunnlag for medisinstudenter eller spesialistutdanning i Norge.

\section{Hans Flaatten}

KSK/Intensiv

Haukeland universitetssykehus 